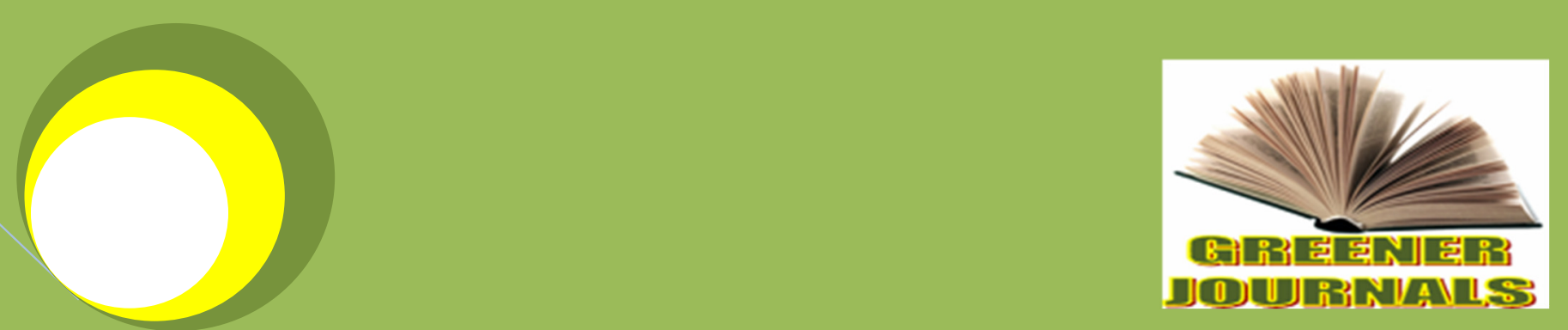

Greener Journal of cconomicsand Accountancy

ISSN: 2354-2357

Submitted: 04/09/2017

Accepted: 11/09/2017

Published: 15/09/2017

DOI: http://doi.org/10.15580/GJEA.2017.2.090417119

'True' Federalism in a

well-structured

Nigeria: The Panacea

to her Economic

Development

Challenges

By

Nwaeze, Nnamdi Chinwendu 


\title{
'True' Federalism in a well-structured Nigeria: The Panacea to her Economic Development Challenges
}

\author{
Nwaeze, Nnamdi Chinwendu
}

\author{
Department of Economics, University of Port Harcourt \\ E-mail: nwaezennamdi@ yahoo.com
}

\begin{abstract}
Nigeria is bedeviled with enormous economic and national developmental challenges. These challenges include but not limited to political instability, extreme poverty, high rate of unemployment, low and unstable economic growth, dearth of infrastructure and colossal depreciation of the Naira; others include militancy, regional agitations and/or resentment, insurgency, and corruption. This paper is a theoretical attempt to adduce reasons why Nigeria has not made meaningful economic and national developmental progress. The position of this paper, therefore, is that Nigeria as it is presently constituted is suffering from at least three major deformities; political, economic and social. 'True' Federalism refers to a political arrangement between governments whereby powers of government within the country are shared between a national country wide governments and federating units in such a way that each exist as a government separately and independently from the others. Federal political orders are therefore, most desirable as an interesting solutions to accommodate differences among populations divided by ethnic, economic or cultural cleavages like Nigeria. This paper therefore concludes that Nigeria's version of Federalism having been distorted historically, politically, socially and economically, is the bane of her economic development as it breeds instability, corruption, unproductive consumption and laziness in her political economy. As a consequence, therefore, conventional economic theories and policies may not be effective to remedy the enormity of her developmental challenges, without pulling down the entire architecture of her current political economy. The paper recommends holistic revolution of Nigeria's political economy by enacting a new and true Federalist Constitution that will enshrine state or zonal independence and autonomy in terms of government powers and economic resources. This would restore federal stability and healthy competition which are catalysts to economic and national development.
\end{abstract}

Keywords: Political economy, federalism, economic development, corruption, political order, instability, deformity and extreme poverty.

\subsection{INTRODUCTION}

Nigeria's enormous economic challenges could be said to have developed considerable resistance to economic theories and policies, which have been previously as well as currently proffered to ameliorate them. This resistance could largely and rightly be attributable to the fact that these economic challenges have more of political rather than economic undertones. These challenges include, low growth, high rate of unemployment, local currency depreciation, high interest rate, low per capita income and corruption; as well as dearth of social and economic infrastructures, high rate of inflation, commodity based economy, insecurity, poor access to energy and credit, import dependent and/or low domestic productive capacity among others. However, issues and discourses on the political economy of Nigeria have not been given utmost priority by policy makers and scholars in analyzing and/or understanding the enormous economic challenges bedeviling the country since independence. The high hopes of the nation's founding fathers at independence in 1960 of building a fast developing economy in particular; a prosperous and united nation in general, could be said to have remained a mere wish which has not taken off till date. While Nigeria still suffers from her 'false start', the 'Asian Tiger' countries like South Korea, China, Malaysia and Singapore who was seen as Nigeria's peers in the late 1950s and early 1960s have overtaken Nigeria to emerge from being Third World countries to become developed economies.

Prior to Nigeria's independence in 1960, the Macpherson Constitution of 1954 recognized a regional structure in the nascent nation, Nigeria, which allowed each region to explore, exploit and harness economic and non-economic resources found in their regions for regional development. The regions had a healthy rivalry and competition that was pro-developmental as each region strived to outwit each order in terms of developmental 
trajectory. Regions were allowed to develop at their own pace without being burdened with a nationwide development needs. For instance, the regional structures was instrumental to the North in developing a thriving niche in Agriculture that led to the groundnut pyramid; the West carved a niche in cocoa production and subsequently introduced free education in the region; the Eastern region on the other hand had palm oil production and commerce as their strength and was able to generate revenue to develop their region. It is imperative to state here that the University of Nigeria, Nsukka, the University of Ife (now OAU) and the Ahmadu Bello University, Zaria were built by regional governments when Nigeria had a functional federal system. The period between 1960 and 1966 is generally regarded as the most prosperous and progressive era in Nigeria's political and economic history. This regional structure was however truncated by the military coup of 1966 and the ensuing civil war that followed between 1967 and 1970; as well as succession of military rule which seized power for 29 years out of Nigeria's 57 years of independence (Akande, 2017). These events led to the creation of states, boundary delineations and promulgation of several unitary Decrees which ultimately discarded the regional structures in Nigeria. These distortions of the roundly negotiated founding structures of Nigeria by the military junta have held Nigeria's development stagnant if not retrogressive politically and economically to date.

Political economy undertakes the economy to mean the interplay of politics and economics and the role of power in economic decision making. It is a holistic approach to underscore the roles both political and economic elites play in influencing resource ownership and or allocation; not just from the economic sense rather as a broad discipline that incorporates both economic, political and historical perspectives and variables in analyzing the operations of the economy. As observed by Todaro and Smith (2011), a political economy attempts to incorporate economic analysis with practical politics. Thus, the political economy views economic activity in its political context. It goes beyond conventional economics to study the interrelation, among other things, the social and institutional processes through which certain groups of political and economic elites influence the allocation of scarce productive resources. It becomes imperative, therefore, for any economy desirous of development to pay utmost attention to how it is governed politically and also lay special emphasis on the processes of how those that are to govern emerges. These political processes bed the beginning of economic emancipation and development. A nation who gets the political and leadership processes right would intermittently get it right economically as the allocation and control of economic (productive) resources chiefly rests on the shoulders of those who holds political powers. Whereas the developed economies have developed political cultures and stable government as well as seamless transition processes, political uncertainties, poor political and governance structures and tyranny are the banes of Third World countries especially in sub-Saharan African countries. The political developments in Nigeria and other sub-Saharan African countries could rightly be said to have chiefly accounted for their perennial underdevelopment.

Consequently, therefore, Nigeria's persistent economic woes cannot be unconnected with her political order and history. For instance, political uncertainties arising from the events and the aftermaths of the 2015 general election in Nigeria; the delayed passage of the annual budget in 2016 as well as the inability of the Federal government to appoint Ministers to constitute the cabinet more than six (6) months after taking over the mantle of governance, contributed to a greater degree in dragging Nigeria's economy into recession, with a GDP contraction of -1.57 percent in 2016 from a GDP growth of 6.4 percent and 2.79 percent in 2014 and 2015 respectively. Also, the annulment of the results of the 1993 general election by the military government led by General Ibrahim Babangida, heralded untold economic and human losses as well as properties and ultimately threw Nigeria into anarchy. The shocks was evidently transferred to the economy as real GDP growth fell from 2.19 percent in 1992 to 1.57 percent in 1993 and 0.29 percent in 1994 . The exchange rate of the Naira also depreciated princely more than 100 percent from N9.91/\$1 in 1991 to $\mathrm{N} 22.05 / \$ 1$ in 1993 and N21.89/\$1 in 1994 respectively. Further evidences can be drawn from the truncation of the Second Republic (1979-1983) government led by Alhaji Shehu Shagari by a military coup orchestrated by General Muhammadu Buhari, who incidentally is the current President of Nigeria. Although the Nigerian economy was battling with economic contraction with a GDP of -1.79 percent in 1982, the contraction in GDP was heighted in 1983 after the dethronement of the democratic government with a contraction in GDP of -7.58 percent (CBN, various)

Despite the fact that Nigeria prides herself as a 'Federal' state, evidences show that it is far from what federalism entails. The concept of 'True' federalism relates to a political order where power is divided between a central government and other regional or constituent units. Such devolution of powers are entrenched in the constitution; well spelt out and unambiguous. Such powers may be shared in different ways; sometimes with a stronger centre like Canada, or weaker centres like the United States of America and Australia. In the case of Nigeria's federal system, its' characteristics are more unitary than federalist. Therefore, proponents of 'true' federalism have argued that such distortions in political order and/or arrangement is in fact antithesis to development as it slow down or stagnate development. As observed by Okowa (1994) 
"....the Nigerian political economy has been structurally damaged and deformed by systemic corruption financed by oil. What has been left behind can no longer be said to be true capitalist system. Rather, we now have a system in which more and more people have come to realize that hard work does not pay; wealth is to be made by being well connected to the state. It involves a social bend of mind that is anti-production. It is Abdulistic. Hence, we have Abdulistic capitalism.......the link between the input of factors of production and output is damaged, for the politically connected get all the money without working".

Succinctly put, therefore, the current structural arrangement on which Nigeria is built and administered have both political and economic deformities. Politically, Nigeria's federal system could be best described as unitary, unbalanced and unsustainable. Firstly, power is highly concentrated at the centre or the Federal government at the expense of the other two levels of government (state and local government). Secondly, the 1999 constitution upon which the country is presently running is basically a military, unitary and imperfect constitution, which does not have much bearing to the will or wish of the people. Thirdly, there is also the lack of social justice or the rule of law; while the tussle for power is not motivated by service, rather by self-accumulation of wealth and greed by the elites. Economically, production is what drives conventional capitalism. In the case of Nigeria, politics, corruption, political patronage and unproductive consumption are the driving forces of our economic system. Secondly, the public sector and/or public finance is the chief conductor or driver of Nigeria's economic growth and development. The public sector and fiscal policy plays a major role in determining the direction of economic activities in Nigeria. However, fiscal policy operations in Nigeria could be said to have been the bane of Nigeria's economic growth. For instance, since the early 1960s, Nigeria's annual budget has been predicated on oil prices, oil outputs and oil revenue as expected revenues are benchmarked with projected oil prices. Should there be an oil boom; Nigeria would be prosperous while the reverse has been the case when there are shocks in oil prices. Quoting Usman, (2009)

\begin{abstract}
"Growth, wealth creation and poverty reduction are all undermined when public financial management and taxation are weak. Fiscal policy's full potential will not be realized until good and accountable expenditure and taxation systems are put in place. Overall, fiscal policy reveals more about the political priorities underpinning a country's development strategy than any other area of policymaking. The problem with Nigeria is that we have, concentrated more on how to share poverty than how to create wealth. The intensity of the struggle, moreover, has been so fierce, divisive and selfish that we have merely succeeded in further impoverishing ourselves".
\end{abstract}

With about 80 percent of Nigeria's revenue coming from oil and gas and accounting for over 90 percent of foreign exchange earnings, fiscal policy in Nigeria has been heavily influenced by oil driven volatility impacting both revenue and expenditure. Since 1970, both revenue and expenditure have been very volatile while increasing over time. In periods with high oil prices, such as in 1979- 1982, 1991- 1992, 2000- 2002, 2005- 2007 and 2011-2014 revenue and expenditure have increased considerably. Despite the dwindling oil revenues recorded in some years, due largely to a fall in the international prices of oil, which climaxed in 2008 and recently in 2014, public expenditures have not been scaled down to reflect the decline in revenue. This volatility in oil revenue has led to Nigeria practicing a fiscal policy regime best described as boom- bust policy. The implications of such boom- bust fiscal policy include the transmission of oil- volatility to the rest of the economy as well as disruptions to the stable provision of government service, and stagnation of economic growth. This has added to the failure over the years of public expenditure, neither facilitating the diversification and growth of the non- oil sectors or reducing poverty (World Bank, 2009). There has been fiscal rascality since independence which are not sustainable due to the fluctuations recorded in oil prices and revenues over the years, and this unsustainable fiscal profligacy has thrown the economy into serious macroeconomic problems that has remain unabated.

Government expenditure expansions have been financed through unsustainable public borrowing that has culminated into Nigeria budgeting about 24 percent of the 2017 federal government budget to debt servicing which amounted to over N1.8 trillion. This figure is over 65 percent of government's current revenues. The implication is that for every N1 Nigeria makes, over 65 kobo is voted for debt servicing. This suggests, therefore, that Nigeria has a debt burden that is unsustainable as well as anti- development. For instance, the stock of Federal Government domestic debt outstanding at the end of December 2009 stood at N3.228 trillion, representing an increase of 39.1 per cent over the level in 2008. External debt in 2009 stood at US\$3.9 billion representing a growth of 6.6 per cent over the level at the end of 2008 fiscal year. Total debt service payment in 2009 stood at N542.5 billion, or 2.2 per cent of GDP and comprised N63.8 billion or US $\$ 0.43$ billion for external and N478.7 billion for domestic debt servicing. These indeed buttress the fact that Nigeria's fiscal domain has been characterized by an unprecedented rate of debt accumulation even in times of unprecedented oil boom and robust foreign reserves. Government debt (domestic and 
external debt) has increased continuously in Nigeria over the years. It grew from N13.526 billion in 1981 to N69.892 billion in 1986 and further to N960.994 billion in 1996. It assumed a continuous rising trend moving from N1.170 trillion in 1998 to N3.995 trillion and N6.260 trillion in 2000 and 2004 respectively. The value of government debt dropped to N4.220 trillion in 2005 and further declined to N2.204 trillion in 2006 mainly as a result of the debt forgiveness granted to Nigeria by the Paris Club in 2005. However, total debt outstanding stood at N3.818 trillion at the end of 2009. The total Government debt profile have continued an astronomical increase which culminated into a total Government debt of N7.554 trillion, N12.604 trillion and N17.360 trillion as at December 31, 2012, 2015, and 2016 respectively. The sustained fiscal deficits in Nigeria have not only had its toll on the humongous total debt profile but also have continued to drain government resources in the form of loan servicing. For instance, domestic debt servicing increased from N865.81 billion in 2014 to N1.02 trillion and N1.236 trillion as at December 2015, and 2016 respectively. The figures of 2015 and 2016 debt servicing shows increase of about N208.76 billion. Of the N1.02 trillion spent in 2015, a whopping sum of N993.13bn was spent on interest payment alone while only N25 billion was spent on repayment of the principal. The 2016 figures are not better either. Out of the N1.236 trillion spent on debt servicing an interest payment of $\mathrm{N} 839.79$ billion was made on funds borrowed from FGN bonds while the sum of N3335.58 billion interest was paid as Nigerian Treasury bills (DMO, Various); (CBN, 2015).

This paper, therefore, is an attempt to challenge the existing narratives that these enormous economic growth and development challenges that have bedeviled Nigeria's chequered history can be ameliorated with conventional economic theories and/or policies. The approach adopted by this paper is revolutionist; an institutionalist version of political economy which seeks to explain and solve the economic problems with both economic and 'non-economic' variables. This is in consonance with the position of Okowa (1994) who acknowledged that even those economists, who utilize conventional analytical methods, willingly concede the inappropriateness of the conventional methods of analysis in the treatment of modern world. This was also collaborated by the work of Keynes (1936:298) who aptly posited that "too large a proportion of recent 'mathematical' economics are mere concoctions, as imprecise as the initial assumptions they rest on, which allow the author to lose sight of the complexities and interdependencies of the real world in a maze of pretentious and unhelpful symbols". The position of this paper, therefore, is that the economic and developmental challenges of Nigeria cannot be explained, analyzed and/or ameliorated with conventional economic methods without adequate framework that recognizes the interdependencies of the society, politics, history and the economy. Nigeria is indeed a peculiar society with peculiarities in her history, way of life as well as political and economic organizations; hence requires both conventional and 'unconventional' approaches to arrive at workable solutions.

\subsection{BRIEF LITERATURE REVIEW ON FEDERALISM}

The central question and argument about federalism is that of devolution of powers amongst the federating units. Should the centre be made weaker by devolving more powers to the other components; or should the centre be made stronger by giving more powers to the centre at the expense of the other components that make up the federation? Accordingly, Moodle (2014) defines federalism as the theory or advocacy of federal principles for dividing powers between member units and common institutions. In federal political arrangements, therefore, sovereignty is non-centralized and must be between at least two levels to enable units at each level have final authority including self-governing in some area. Federal political orders are most desirable as interesting solutions to accommodate differences among populations divided by ethnic or cultural cleavages yet seeking common, often democratic order. In this stead, philosophical contributions have addressed the dilemmas confronting some federations like Iraq, Canada, Nepal, Australia, India, Russia and Nigeria.

Federalism has different species which includes federation, unions, confederations, leagues and decentralized unions. A federation, therefore, involves a territorial division of power between constituent units; variously called 'provinces' 'cantons', or confusingly 'states' and a common or central government. This devolution of power is naturally engrained in a constitution which neither member unit nor common government can alter unilaterally. This political order is different in a unitary order where decentralized authority can typically be revoked by the central government unilaterally. Confederation in contrast, is seen to mean a political arrangement with a weaker centre than a federation, often dependent on the constituent units (Watts, 1998). There are some peculiarities inherent in a confederation political order; firstly, member units may legally exit the union; secondly, the centre is subject to member unit veto on many issues; thirdly, the centre lacks an independent fiscal and electoral base and member units do not cede authority permanently to the centre; among other notable peculiarities.

Several scholars and theorists have attempted to make quality contributions to the issue of federalism and political arrangement over the years. Prominent among them are early contributors in the $17^{\text {th }}$ and $18^{\text {th }}$ centuries like Johannes Althusius (1557-1630), Ludolph Hugo (ca. 1630-1704), Charles de Secondat, Baron de Montesquieu (1689-1755) and David Hume (1711-1776). In his contribution, Immanuel Kant in his work titled On Perpetual Peace (1796) cited by Moodle (2014) argued in favour of a confederation political order as being able to guarantee peace in 
the state or union. He was of the opinion that a confederated state will preserve and secure the freedom of each constituent unit which guarantees continued peace in the union. The work of J.S Mill titled Considerations on Representative Government (J.S Mill, 1861 cited by Ojo, 2017 \& Moodle, 2014) ), suggested federations among "portions of mankind" not disposed to live under a common (central) government, to prevent wars among themselves as well as protect against aggression. He as well listed three necessary conditions for a federation: sufficient mutual sympathy "of race, language, religion, and above all political institutions, as conducing most to a feeling of identity to a political interest"; no member unit is so powerful not to require union for defense nor tempt unduly to secession; and thirdly, rough equality of strength among member units to prevent internal domination by one or two. Quoting his law of federal stability "a federation is morbid if one part is bigger than the sum of the other parts". This political order, therefore, does not entrench equality of strength among member units and therefore, guarantees that one unit of the union will dominate the other units.

\subsection{Argument for Federalism}

As observed by Elazar (1987) many reasons why federalism is most desirable have chiefly been centered on the need to promote various forms of liberty which guarantees non-domination, immunity or enhanced opportunity sets. Some of the arguments for federalism are highlighted below;

$\checkmark$ Federalisms may foster peace by preventing internal domination and crisis which could lead to wars and fears of war in a state. Such political order may guarantee the state to become jointly powerful enough to dissuade external aggressors as well as prevent aggressive and preemptive crisis or wars among themselves

$\checkmark \quad$ Federalisms can promote economic prosperity. This could be achieved by removing internal barriers to trade, through economies of scale and retention of resource ownerships by constituent units. Decentralization of resource ownership is most likely to address the problem of optimal allocation of economic and noneconomic resources. This is a typical approach to optimal income redistribution that could foster peace and economic prosperity of the federating state.

$\checkmark \quad$ In federalism, abuse by the centre is less likely, as it may protect individuals especially the minorities against political authorities by constraining state (center) sovereignty (Watts, 1999). Constitutional allocation of powers to member unit protects individuals from the centre. Constituent units may, therefore, checkmate central authorities and prevent excessive action contrary to the will of the minorities

$\checkmark$ Federalisms can also be preferred as the appropriate political order in that it may promote better cooperation, justice, equity and equality; or other values among and within member units

$\checkmark$ More specifically, federal arrangements can accommodate minority constituents desirous of selfdetermination and the preservation of their culture, language or religion. Such spelt out autonomy and immunity arrangements are obviously preferable to the political conflicts that might arise from such groups' attempt to secession. Where these are not constitutionally entrenched, central authorities may elect to respond with human right abuses, civil wars or ethnic cleansing to prevent such secessionist movements.

In contrast, the major argument against federalism is that a weaker centre may spell doom to the union. This is because there may be threats and counter threats for secession especially from the minority units. However, it is imperative to note here conclusively that, true federalist political order structured on equity, justice and equality among constituent units would foster peaceful co-existence, economic prosperity through common trade and economic integration.

\subsection{Requirements for True Federalism}

\section{Existence of Two Constitutions; Federal/State Constitutions}

To preserve shared powers and effectiveness between the central government and other constituent units in true federalism, the existence of more than one constitution is paramount. In consonance to this, Adesina (2017) cited Lord Haldene in the case of ATTORNEY-GENERAL FOR COMMONWEALTH OF AUSTRALIA $v$ COLONIAL SUGAR REFINERY COMPANY that said; "The natural and literal interpretation of the word "Federal" confines its application to cases in which States, while agreeing in a measure of delegation of powers of a common government yet, in the main continues to preserve their regional constitution". Arguing on the appropriateness of a single constitution in a Federal political order, Nwabueze (1983) posits that "One single constitution for all the Governments involved, both the Federal and State is a manifest contradiction". The issue of more than one constitution is also not alien to Nigeria's political history and development. For instance, the Independence constitution of 1960 and the 
Republican Constitution of 1963 accommodated separate constitutions for both the Federal government and the Regions. The 1963 Constitution in particular made provisions for the establishment of Regional Constitutions, in section 5(1).... "Subject to the provision of this constitution (Federal Constitution) the Constitution of each region shall have the force of law throughout the region and if any other law is inconsistent with the Constitution, the provision of that Constitution shall prevail and the other law shall to the extent of its inconsistencies be void". Therefore, such arrangement gives power to the constituent units or regions to adjudicate laws that are consistent with their culture and developmental aspirations.

\section{Autonomy of Governments}

Autonomy of each Government is an existential prerequisite to federalist political order. This characteristic suggests the existence of distinctiveness and independence of each government from the control of the other. This characteristic, therefore, becomes essential as it guarantees that each government, central or regional, must exist, not just as an adjunct of the other, but as an autonomous entity, with utmost freedom of being able to carry out its own will in the conduct of its affairs, devoid of direction from the other government. Thus, autonomy to each government ensures that each government takes utmost responsibility in will, thoughts and actions that supports its aspirations without interference from the other(s). A collaborated feature to this is, therefore, that of mutual noninterference, which suggests that each government must not impede, obstruct or otherwise interfere with the other acting within its own powers

\section{Meaningful Number of States/Regional Governments.}

As submitted by Adesina (2017) the multiplicity of interest groups reacting upon one another to produce equilibrium is what makes Federalism to thrive. This is because a multiplicity of units creates a feeling of inter-dependence, which in turn emboldens co-operation and mutual tolerance.

\section{Meaningful Independence}

The existence of a certain degree of meaningful independent relationship which rests upon a balanced division of powers and resources, sufficient enough to support its structures should exist between the Central government and the Regional government in Federalism. To this, therefore, the power sharing arrangement should not be lopsided in favour of any Governments, so as not to make either so powerful that it is able to subvert or bend the will of the other to his own

\section{Equality of Status as Between the Federating Units.}

This is agreement with J.S Mill's law of federal stability (1861, cited by Ojo, 2017) in which he stated that a federal system should not be morbid; thus, underlying the importance of equality in size and powers of the individual regional or constituent governments. It therefore, becomes implicit and imperative in the federal system, that the powers of the individual regional governments and their relationship with the central government should be the same; as well, that no regional government should be allowed special position with regard to the central government. Such inequality breeds arrogance and conflict which could have a grave consequence on the entire union.

\subsection{Brief Overview of Nigeria's Journey to Federalism}

Nigeria's journey towards Federalism predates her independence. The birth could be traced to the introduction of the Richard Constitution in 1946, which had a quasi-federal structure. While trying to write a new constitution for Nigeria, Sir John Macpherson opted for wide range consultations via widely distributed questionnaires in 1951 . The purpose was for Nigerians to choose the system of constitution they wanted for the eminent emergence of the country. One major contribution to this quest was a memorandum submitted to the constitutional conference in 1950 by the Nigerian Youth Movement which stated that "it is a matter of general agreement that a lasting unity of the people of the vast country can only be achieved through federation not fusion. Consequently, it is absolutely necessary to lay the foundation for Federation now by dividing the country into the regions that will form the units of the proposed Federal Constitution" (cited by Adesina, 2017). This unanimous position of Nigerians led to the declaration of Nigeria as a Federation consisting of three regions; the Northern region, the Eastern region and the Western region with Lagos as the Federal Capital Territory, by both the 1951 and 1954 Constitutions. One major highlight and strength of the 1954 constitution was the promotion of regional autonomy, which indeed took into consideration the diversities and the cosmopolitan nature of Nigeria. The constitution, therefore, permitted the regions to prioritise government 
and develop at their own pace. This federal system of regional arrangement was maintained by the independence and Republican Constitutions of 1960 and 1963, which gave powers especially fiscal provisions and economic powers to the regions.

However, this arrangement of regional autonomy which guaranteed true federalism or federal principle, which was chiefly the bond of unity in diversity at independence went into extinction as a result of the military misadventures, starting with the military coup of 1966 and the counter coup of 1967, as well as the civil war which ensued between 1967 and 1970. This was the birth of unitary system of government which has indeed bequeathed to us the present lopsided, impracticable, unsustainable and divisive federalism. The Unification Decree No 34 as enacted by General Aguiyi Ironsi in 1966 ultimately wiped out the gains of the regional autonomy dispensation in Nigeria. In his declaration, Ironsi stated that:
...." Nigeria shall on the $24^{\text {th }}$ of May, 1966 cease to be a federation and shall accordingly as from that day be a republic by the name the Republic of Nigeria, consisting the whole territory, which immediately before that day was comprised in a federation." (Oladesu, 2017)

The above declaration dealt a fatal blow to Nigeria's federal principle and thus, Federalism was abolished! Things have remained the same with successive military juntas and the interjecting civilian administrations in Nigeria.

\title{
3.0 METHODS AND ANALYSIS
}

This paper is basically a theoretical exposition which adopts institutionalist political economy approach to analyze Nigeria's economic challenges in relation to her history, politics and socio-economic accounts. Institutionalist political economy recognizes the interdependence of social science disciplines, therefore, economic problems are intertwine with historical, social and political problems, hence, the need to analyze and proffer holistic remedies to ameliorate them effectively (Jhinghan et al, 2012).

\subsection{Research Analysis}

The analysis of this study is premised on this question; what then is wrong with the current political and economic structures of Nigeria? In the words of Nwabueze (1983)

\begin{abstract}
"Federalism is an arrangement whereby powers of government within the country are shared between a national country wide government and member of a region territorially localized government in such a way that each exist as a government separately and independently from the others operating directly and independently on persons and properties within its territorial area with a will of its own and its own apparatus for the conduct of an authority in some matters exclusive of all others. Federalism is thus essentially an arrangement between governments, a constitutional device by which powers within a country are shared between two tiers of government rather than among geographical entities composing different people.....Federalism is predicated upon the existence of a society composed of various geographically segregated groups divided by wide fundamental differences of race, religion, language, culture, or economic. Its purpose is to enable each group free from interference or control by the others to govern itself in matters of local concern leaving matters of common interest to be managed centrally, and those which are of both local and national concern to be administered concurrently".
\end{abstract}

It is, therefore, evident that Nigeria as she is presently constituted is structurally deformed. These deformities, however, emanated from the political order which has consequently led to economic deformities and the attendant and/or litany of economic growth and development challenges. Virtually all the elements and characteristics that define true Federalism are absent in Nigeria's version of 'federalism'; power sharing between the centre and the 'federating' states is skewed; separateness and independency of constituent units is nonexistent; and most importantly, economic powers and resources are concentrated at the centre. This paper shall, therefore, enumerate these political, social and economic structural deformities and use same for our analysis 


\subsubsection{Political Deformity}

\subsubsection{The 1999 'Military/Unitary’ Constitution}

But for systemic corruption, the 1999 constitution is arguably the most single element that has undermined Nigeria's development politically and economically. This is aptly captured by Akande (2017) who stated that: "....The 1999 Constitution is the greatest misadventure since Lord Lugard's amalgamation of 1914. The Constitution puts emphasis on spending rather than making money, thereby intensifying the battles for supremacy between the legislature and the executive, while the judiciary is being corruptly tainted and discredited...the constitution breeds and protects corrupt practices and criminal impunities in governance...it should only be scrapped as bad relics of military mentality and replaced by the 1963 Republican Constitution to enable a transition for the writing of a suitable constitution. Otherwise, the 1999 Constitution would continue to dwarf Nigeria's economy and stifle the country's social structure pending a disastrous and catastrophic bankruptcy". The fact remains that several provisions in the 1999 Constitution are alien to all known principles of Federalism. Few expository will help to drive home the obvious frustration inherent in the above statement.

Firstly, the 1999 Constitution shows clear evidence of concentration of power at the centre. Fair and equitable sharing of power between the centre and the component units that make up the Federation is one of the major elements of true Federalism. The provisions of the 1999 constitution are clearly an aberration to equity in power sharing between the Federal government of Nigeria and the federating states. These provisions have made the President of Nigeria the 'most powerful President' in the world in terms of powers he commands. The Legislative list in the 1999 constitution evidently indicates this. There are 68 items in the executive list of the 1999 constitution and 16 items in the concurrent list. The numbers are of course not the main absurdity rather the nature of the items on the list also reveals the dominant status of the federal powers. Critical economic items like mines, minerals, including oil fields, oil mining, geological surveys and Natural gas (item 39), are all vested at the centre; Borrowing of money within and outside Nigeria for the purposes of any State (item 12); Police and other government security services (item 45); census (item 7) (There is no reason why a state government cannot organize a population census of its state, to enable it plan its fiscal policy and development programs etc). Other items in the executive list like 'federal' roads, railways et al have indeed contributed immensely to dearth and decay of infrastructure across the nation, which has debilitated Nigeria's development (FRN Constitution, 1999).

The fiscal provisions of the 1999 which concentrates all economic power in the government at the centre, constitutes a major impediment to economic development. This singular provisions stifles any sensible desire and drive to diversify the economy and the revenue base of Nigeria, as Nigeria has not been able to leverage on the combined capacity of the 36 states, as they have become baggage and mere appendages to the federal government which has ultimately hinders the nation's quest for economic development. The fiscal provisions of the 1999 Constitution, therefore, have not allowed the federating states to harness their comparative advantages, to develop and finance infrastructure, provide social services as well as aid the expansion of the national economy. It may be argued that the Nigeria's golden economic era came in the 1950s and the 1960s when the country was well structured as a 'true' federation. The existing regions were not restricted by a suffocating unitary structure and constitution (like the 1999 Constitution), which led to the regions being able to harness their resources in line with their comparative advantages. The 1963 Republican Constitution, for instance, was instrumental to the achievements recorded as a result of its distribution of economic powers to the regions equitably and broadly too. In the same manner, the 1954 Constitution which enshrined regional autonomy was a catalyst to economic development, as this opened up healthy competition and rivalry among the regions. Unlike the 1999 Constitution, the 1954 Constitution, specifically placed items like arms, ammunition and explosives, commercial and industrial monopolies, registration of business names, Police and other security services and census among others under the concurrent legislative lists. With only 16 items on the concurrent list, the 1999 Constitution has, therefore, made the Federal Government too large as well as too difficult to operate effectively and efficiently. It is imperative to note here that the constitutional provision anomalies are products of 27 years of military dictatorship which through previous constitutional provisions away while arrogating powers unilaterally to the centre.

Furthermore, the 1999 Constitution has, therefore, altered the pattern of fiscal federalism in Nigeria. As observed by Okowa (1994), fiscal federalism was based on the derivation principle, prior to the era of oil boom of the 1970s. For instance, in 1967, 50 percent of mining rents and royalties went to the relevant state government from which the rents were derived. Unfortunately, however, this derivation principle and allocation was gradually but consciously decimated (even to zero at some stage of our nationhood) as oil revenue increased over the years. The 13 percent derivation that is presently being allocated to the oil producing states came into existence as a result of militancy agitations by the oil producing communities and states. Okowa (1994), therefore, argues that: 
"the majority of the nationalities who benefited from derivation when it favoured them were those who pushed forcefully for a dethronement of the derivation principle when it was realized that the new beneficiaries of the principle were the people of the minority nationalities.....the elimination of the derivation principle in the face of rising oil-generated revenue meant that whoever controlled the Federal Government had the key to enormous wealth".

It is, therefore, logical to conclude that these structural deformities orchestrated by the provisions of the 1999 Constitution has exacerbated corruption, instability, economic and national development challenges that have bedeviled Nigeria's chequered history. The 'do or die' quest for political powers and the monetization of politics in Nigeria may not be unconnected to the craze to seize power to control the 'sharing' of oil rents.

Finally but not exhaustively, a constitution that bequeaths a minimum of 36 ministers and thousands of aids to the President; a constitution that bequeaths 109 Senators and 360 Federal House of Representative members with over 3,500; a constitution that bequeaths 36 governors and deputy governors, state commissioners and thousands of aids; a constitution that bequeaths close to 1,000 State House of Assembly members and their legion of aids; a constitution that bequeaths 774 idle local government chairmen and thousands of councilors with the attendant aids; as well as other numerous parastatals, agencies which have similar responsibilities, therefore, cannot be said to be efficient, sustainable and/or supports the country's quest for economic growth and national development. The economic implication, therefore, is that of inefficiency and waste as major chunk of Nigeria's resources are being spent on less than 5 percent of the population (politicians). Thus, the cost of governance in Nigeria is evidently too high, unsustainable and inherently retards economic growth and development. A point to note, therefore, is that the 1999 Constitution was never negotiated by the people but was handed over to Nigerians by the military who had hitherto distorted the political and socio-economic history and architecture of Nigeria during their almost 30 years of illegitimate rule. Its provisions were, therefore, skewed to favour a section of the country in line with these obvious historical, political and economic distortions. This is chiefly the bane of Nigeria's economic development challenges and political instability!

\subsubsection{Structurally Imbalanced and Morbid Federation}

According to J.S Mill's law of federal stability "a federation is morbid if one part is bigger than the sum of the other parts". Nigeria's version of 'federalism', therefore, fits into this law and has been one of the primary reasons why Nigeria has remained unstable and underachieved. Nigeria as it is presently constituted does not accommodate differing interests, circumstances and diversities of the constituent groups. This has made effort in securing peace and stability of the country, and its survival against the forces of division and conflict in a diverse and heterogeneous society like Nigeria to remain elusive. For analytical minimalism, in terms of land mass, the Northern Region then had 71 percent, Western Region 8.5 percent, Eastern Region 8.3 percent and the Mid-Western Region 4.6 percent. The table below captures the current structural coloration of Nigeria:

Table 3.1: The Structure of Nigeria's Present Political Economy

\begin{tabular}{|c|c|c|c|}
\hline \multicolumn{2}{|l|}{ NORTH } & \multicolumn{2}{|l|}{ SOUTH } \\
\hline Number of States & 19 & Number of States & 17 \\
\hline North East & 6 & South East & 5 \\
\hline North West & 7 & South-South & 6 \\
\hline North Central & 6 & South West & 6 \\
\hline Number of Local Governments & 419 & Number of Local Governments & 357 \\
\hline \multirow{3}{*}{$\begin{array}{l}\text { House of Representatives } \\
\text { North East } \\
\text { North West }\end{array}$} & 191 & House of Representatives & 169 \\
\hline & 48 & South East & 43 \\
\hline & 92 & South-South & 55 \\
\hline North Central & 49 & South West & 71 \\
\hline Number of Senators & 57 & Number of Senators & 51 \\
\hline Federal Allocation & $56 \%$ & Federal Allocation & $44 \%$ \\
\hline States & $57 \%$ & States & $43 \%$ \\
\hline Local Governments & $55 \%$ & Local Government & $45 \%$ \\
\hline \multicolumn{2}{|c|}{ Contribution to Major Revenue Sources $14 \%$} & \multicolumn{2}{|c|}{ Contribution to Major Revenue Sources $86 \%$} \\
\hline Oil and Gas & $0.0 \%$ & Oil and Gas & $100 \%$ \\
\hline Value Added Tax & $28 \%$ *** & Value Added Tax & $72 \%$ \\
\hline
\end{tabular}

Source: Author's computation; Financial data was obtained from the Ministry of Finance and Office of the Accountant General of the Federation. 
From the above analysis on table 3.1, therefore, the political and economic imbalance is evident. This structural imbalance in Nigeria's political economy cannot guarantee peace, stability, progress and/or economic development. Whereas the political structure shows obvious inequalities in the number of states, local governments, Senators, House of Representatives and federally allocated revenues, skewed to favour the North Region, the South Region contributes 86 percent of the revenues used in running the present political architecture. For instance, while contributing a meagre 14 percent of revenues, the North Region receives an average of 56 percent of federally allocated revenues against 44 percent receipts for the South Region which contributes an average of 86 percent of the revenues. The reasons, therefore, for the continued militancy and other regional agitations from the South Region is not far fetch as the region believes that they are massively shortchanged by the current structure of Nigeria and has arguably decelerated the process of national development. Apart from the economic analysis, the structural imbalance of the present structure has given the North the exclusive right to rule the country or decide who rules the country at every point in time. The inequality between the North and South, therefore, has made it virtually impossible for the South to control political power at the centre, given the ethno-regional politics of the country, without power concession from the North. It is a common knowledge and in our collective consciousness, that no one becomes the President of Nigeria without the support and 'blessings' of the Sokoto Caliphate. These inequalities that are being promoted by current political and economic structures are, therefore, antithesis to federal stability, peace, and national development.

\subsubsection{Economic Deformity}

\subsubsection{1 'Feeding Bottle' Federalism}

Nigeria's version of Federalism could be best described as 'feeding bottle' Federalism. A situation where the existential of the 'federating states' and the federal government is dependent on 'sharing' oil rent monthly is far from being an ideal situation that stimulate economic growth as well as sustainable development. Quoting Babalola (2017);

\section{"...I have been an unrepentant supporter and crusader for restructuring of the country because what we have is called federal government but it is indeed a unitary government where states only go for begging of money at the end of every month and no development of any kind is taking place".}

Governance in Nigeria has been turned into beggars' affair where all States feasts on federal allocation for survival. This rent seeking tendencies have led to states jettisoning all forms of viable revenue generation in wait for 'free' federal allocations, under the Joint Account Allocation Committee (JAAC). The table 3.2 is more revealing; 
Table 3.2: Annual State Viability Index (ASVI): Ranking of States by Internally Generated Revenue (IGR) Compare to Federation Account Allocation, 2016

\begin{tabular}{|c|c|c|c|c|c|c|}
\hline $\mathbf{S} / \mathbf{N}$ & STATE & LGAS & $\begin{array}{l}\text { FAAC } \\
\text { ALLOCATION } \\
=\mathrm{N}=\end{array}$ & $\begin{array}{l}\text { IGR } \\
=\mathrm{N}=\end{array}$ & $\begin{array}{l}\% \\
\text { (IGR/FA } \\
\text { AC) }\end{array}$ & $\begin{array}{l}\text { VIABILITY } \\
(\text { IGR>50\% } \\
\text { FAAC) }\end{array}$ \\
\hline 1 & LAGOS & 20 & $178,606,493,854$ & $302,425,091,964$ & 169 & YES \\
\hline 2 & OGUN & 20 & $57,362,408,575$ & $72,983,120,003$ & 127 & YES \\
\hline 3 & RIVERS & 23 & $134,870,667,278$ & $85,287,038,971$ & 63 & YES \\
\hline 4 & EDO & 18 & $59,278,008,837$ & $23,041,425,599$ & 38 & NO \\
\hline 5 & KWARA & 16 & $49,222,542,289$ & $17,253,829,559$ & 35 & NO \\
\hline 6 & DELTA & 25 & $126,621,398,438$ & $44,057,915,472$ & 34 & $\mathrm{NO}$ \\
\hline 7 & KANO & 44 & $111,380,002,329$ & $30,959,027,531$ & 27 & NO \\
\hline 8 & $\begin{array}{l}\text { CROSS } \\
\text { RIVER }\end{array}$ & 18 & $55,771,945,495$ & $14,776,808,331$ & 26 & NO \\
\hline 9 & ENUGU & 17 & $56,123,326,156$ & $14,235,512,227$ & 25 & NO \\
\hline 10 & OYO & 33 & $80,349,610,722$ & $18,879,084,132$ & 23 & NO \\
\hline 11 & $\mathrm{ABI} \mid \mathrm{A}$ & 17 & $54,400,939,511$ & $12,694,839,539$ & 23 & NO \\
\hline 12 & KADUNA & 23 & $78,554,203,037$ & $17,051,864,537$ & 22 & NO \\
\hline 13 & PLATEAU & 17 & $57,794,404,593$ & $9,191,372,277$ & 16 & NO \\
\hline 14 & AKWA IBOM & 31 & $150,238,498,696$ & $23,269,750,752$ & 15.48 & NO \\
\hline 15 & KOGI & 21 & $63,998,636,681$ & $9,569,124,487$ & 14.95 & NO \\
\hline 16 & OSUN & 30 & $62,985,226,855$ & $8,884,756,040$ & 14 & NO \\
\hline 17 & BENUE & 23 & $69,928,787,692$ & $9,556,495,064$ & 13 & NO \\
\hline 18 & BAUCHI & 20 & $68,136,764,933$ & $8,677,265,878$ & 12.73 & NO \\
\hline 19 & ONDO & 18 & 70,343,574,708 & $8,684,406,578$ & 12.34 & NO \\
\hline 20 & TARABA & 16 & $52,769,573,806$ & $5,895,538,974$ & 11 & NO \\
\hline 21 & ADAMAWA & 21 & $58,489,518,680$ & $5,788,979,592$ & 10 & NO \\
\hline 22 & ZAMFARA & 14 & $53,119,877,025$ & $4,777,169,537$ & 9 & NO \\
\hline 23 & $\mathrm{IMO}$ & 27 & $67,717,778,855$ & $5,871,026,976$ & 8.66 & NO \\
\hline 24 & NIGER & 25 & $70,831,185,155$ & $5,881,584,409$ & 8.30 & NO \\
\hline 25 & BAYELSA & 8 & $99,291,071,848$ & $7,905,458,280$ & 7.96 & NO \\
\hline 26 & NASSARAWA & 13 & $47,554,540,407$ & $3,402,616,062$ & 7.15 & NO \\
\hline 27 & SOKOTO & 23 & $65,979,243,303$ & $4,545,765,527$ & 6.88 & NO \\
\hline 28 & KATSINA & 34 & $83,279,473,947$ & $5,545,900,833$ & 6.65 & NO \\
\hline 29 & EKITI & 16 & $47,564,063,908$ & $2,991,041,855$ & 6.28 & NO \\
\hline 30 & GOMBE & 11 & $46,952,352,244$ & $2,941,438,110$ & 6.26 & NO \\
\hline 31 & YOBE & 17 & $53,936,297,357$ & $3,240,867,567$ & 6 & NO \\
\hline 32 & JIGAWA & 27 & $68,522,798,932$ & $3,535,349,908$ & 5.15 & NO \\
\hline 33 & KEBBI & 21 & $60,886,882,102$ & $3,132,343,261$ & 5.14 & NO \\
\hline 34 & EBONYI & 13 & $46,665,951,480$ & $2,342,092,225$ & 5 & NO \\
\hline 35 & BORNO & 27 & $73,800,935,256$ & $2,675,723,063$ & 4 & NO \\
\hline 36 & ANAMBRA & 21 & $60,100,365,047$ & $\mathrm{~N} / \mathrm{A}$ & - & \\
\hline 37 & FCT & & $19,272,644,365$ & $\mathrm{~N} / \mathrm{A}$ & - & \\
\hline & TOTAL & & $2,662,701,994,413$ & $801,951,625,136$ & 30 & NO \\
\hline
\end{tabular}

Source: Extract from Economic Confidential Magazine, 2017; Viability rating is author's threshold

Table 3.2 expressly captures why Nigeria has remained undeveloped and would remain that way if something revolutionary is not done to discourage this trend. For the records, only three states, Lagos, Ogun and Rivers met the viability threshold of generating at least 50 percent of their Federal Account Allocation revenues in internally generated revenue (IGR). If the viability threshold is reduced to 10 percent of FAAC, only 22 states met the criteria. It follows, therefore, that 32 states are insolvent if 50 percent threshold of FAAC is adopted. On the other hand, 14 states are insolvent at 10 percent threshold. Collectively, while the states received $=\mathrm{N}=2.662$ trillion in FAAC revenues, they generated only $=\mathrm{N}=801$ billion in internally generated revenues (IGR). Thus, the states collectively realized 30 percent of FAAC in IGR in 2016. It is obvious, therefore, that the FAAC allocation received by states monthly, serves as a discouragement to the development of local or internal capacities of states. It has made 
states to become lazy not to look inward to discover and develop untapped capacities, where they have comparative advantage thereby generating robust revenues internally. Most states, therefore, lack foresight in revenue generation drive, as well as arm-chair governance financed by 'free money'. This as well has led to heightened corruption where internally generated revenue (IGR) are now used as tools to settle political elites and jobbers who are cronies of state governors, by awarding fictitious revenue contracts that end up in the personal pockets of their cronies and not into the state coffers. There are no justifications why these states are not able to generated revenues that would make them become self-reliant, except for 'free and easy' funds from the centre. Ideally, states especially those in the North region which has comparative advantage in agriculture, ought to take advantage to generate enough revenue to fund their development. When we bring into this debate the fact that, prior to discovery of oil in commercial quantity in Nigeria, agriculture accounted for about 80 percent of Nigeria's revenue and foreign exchange earnings, it is, therefore, evident that rent seeking tendencies of states and the structure of Nigeria's political economy have deformed and undermined economic development of Nigeria. The attraction, therefore, is to lay in wait for the monthly largesse from Abuja, which is funded by oil rents but are brazenly looted and/or spent on unproductive ventures that add no impetus to states or national development.

It is imperative to note further that Nigeria's tax revenues have been below par, which may not be unconnected with rent seeking activities and high corruption index. Nigeria's tax revenue is one of the lowest both in the world and Sub-Sahara Africa.

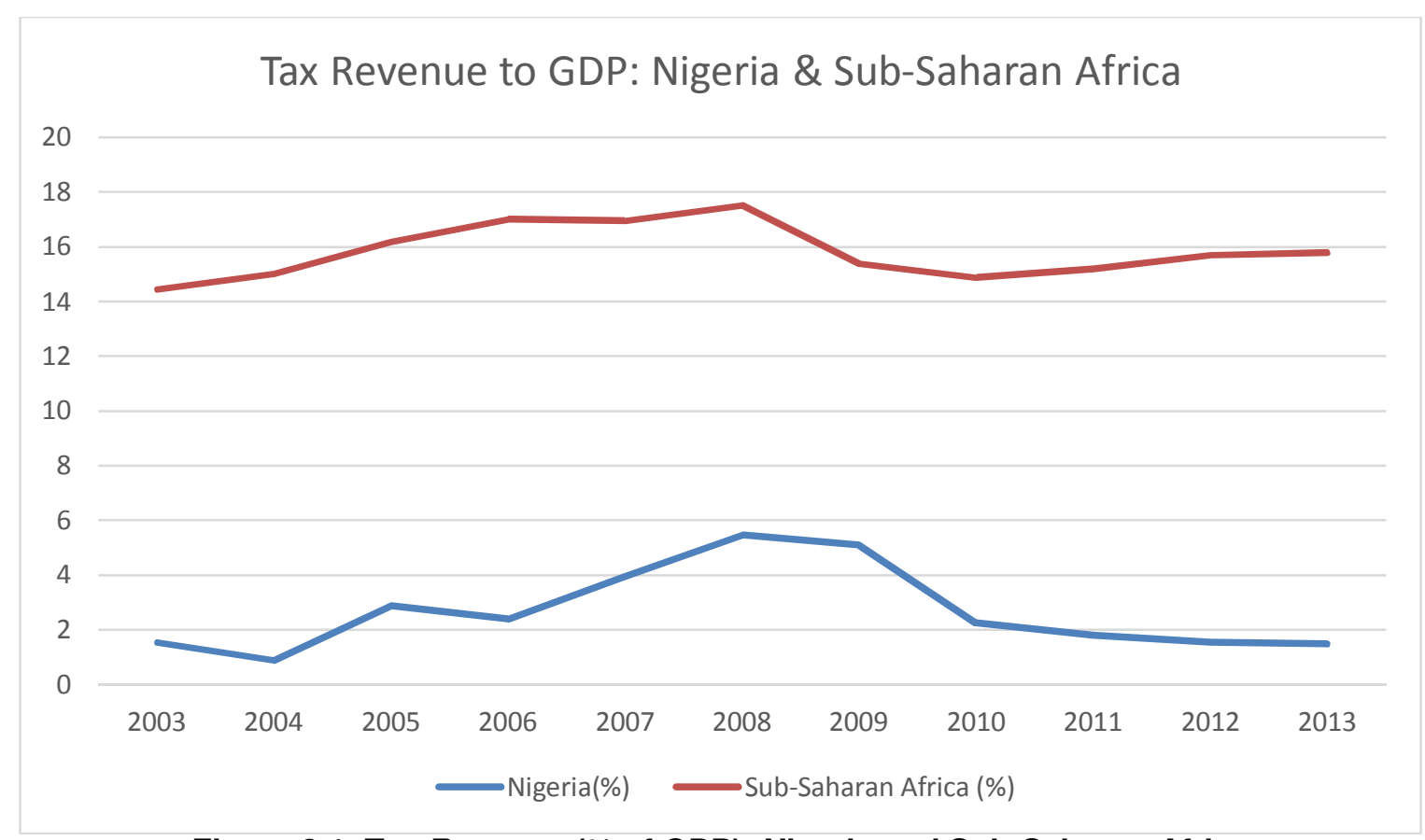

Figure 3.1: Tax Revenue (\% of GDP): Nigeria and Sub-Saharan Africa

Source: Author's computation with data from IMF Government Finance Statistics Yearbook

Whereas tax revenue to GDP ratio for Sub-Saharan Africa averaged over 15 percent between 2003 and 2013 , Nigeria's average in the same period is approximately 2 percent. The 2016 Nigeria's tax revenue to GDP was 6 percent compared to 43.4 percent, 23 percent, 27.2 percent, 39.8 percent and 28.1 percent for Austria, Cape Verde, Zimbabwe, Netherlands and China respectively. It, therefore, follows that Nigeria's tax revenue potentials remain untapped owing to revenues accruing from crude oil sales, which has made us jettison viable taxable ventures.

\subsubsection{Unproductive Consumption}

Nigeria's economic system is evidently characterized by unproductive consumption. Theoretically, higher consumption stimulates economic growth via the multipliers. According to Keynes theory of employment, output, interest and income (1936), a country with a high marginal propensity to consume (MPC) would stimulate employment and growth rapidly than a country with low MPC. As cited by Ohale (2002), the increases in employment 
and national income would be eroded by imports if the domestic productive capacity of the country with high MPC is not developed or underdeveloped, as the increased national income will be spent on importation of goods and services to meet domestic demands. This is, therefore, the case of Nigeria economic structure as presently constituted. While Nigeria can boast of high MPC financed by oil receipts and large population these consumptions have not added much impetus to economic growth and national income. For instance, it is estimated that Nigeria's daily consumption of fuel (PMS) is about 44 million litres. With the current official exchange rate of $=\mathrm{N}=310 / \$ 1$, the landing cost of importing PMS into Nigeria is approximately at $=\mathrm{N}=128 /$ itre. The implication, therefore, is that Nigeria spends approximately $=\mathrm{N}=2.055$ trillion to import PMS consume locally per year. This is indeed Nigeria's lot in recent history as virtually 100 percent of petroleum products consumed locally are imported.

Nigeria's total import to GDP ratio between 1981 and 2015 stood at approximately 21.5 percent. Thus, 21.5 percent of Nigeria's gross domestic product (GDP) is spent on importation of good and services. This may not be unconnected with the undeveloped nature of the manufacturing sector, our penchant for demanding 'anything foreign' and low domestic capacity. For instance, Nigeria's manufacturing sector which ordinarily ought to be the major driver of economic growth, contributes less than 10 percent of Nigeria's gross domestic product (GDP). There is no developed economy that achieved economic development with import dependent tendencies. This is primarily not only because import dependent economies discourages development of the manufacturing sector, it is also inherently unstable as a result of external shocks in terms of imported inflation, exchange rate volatility as well as loss in domestic employment stimulation.

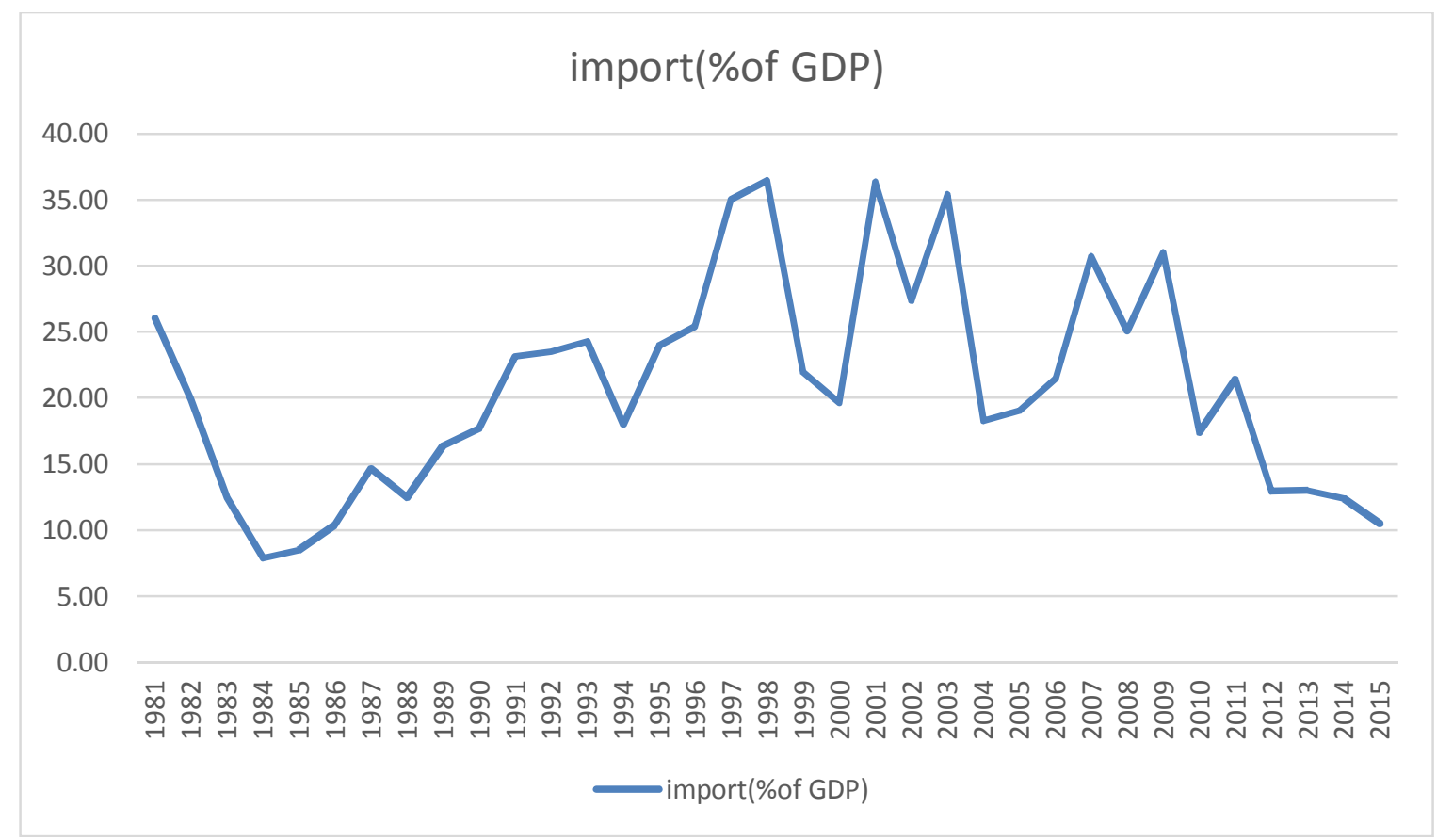

Figure 3.2: Nigeria's Import as Percentage of GDP

Source: Author's computation with data from CBN Statistical Bulletin and IMF 


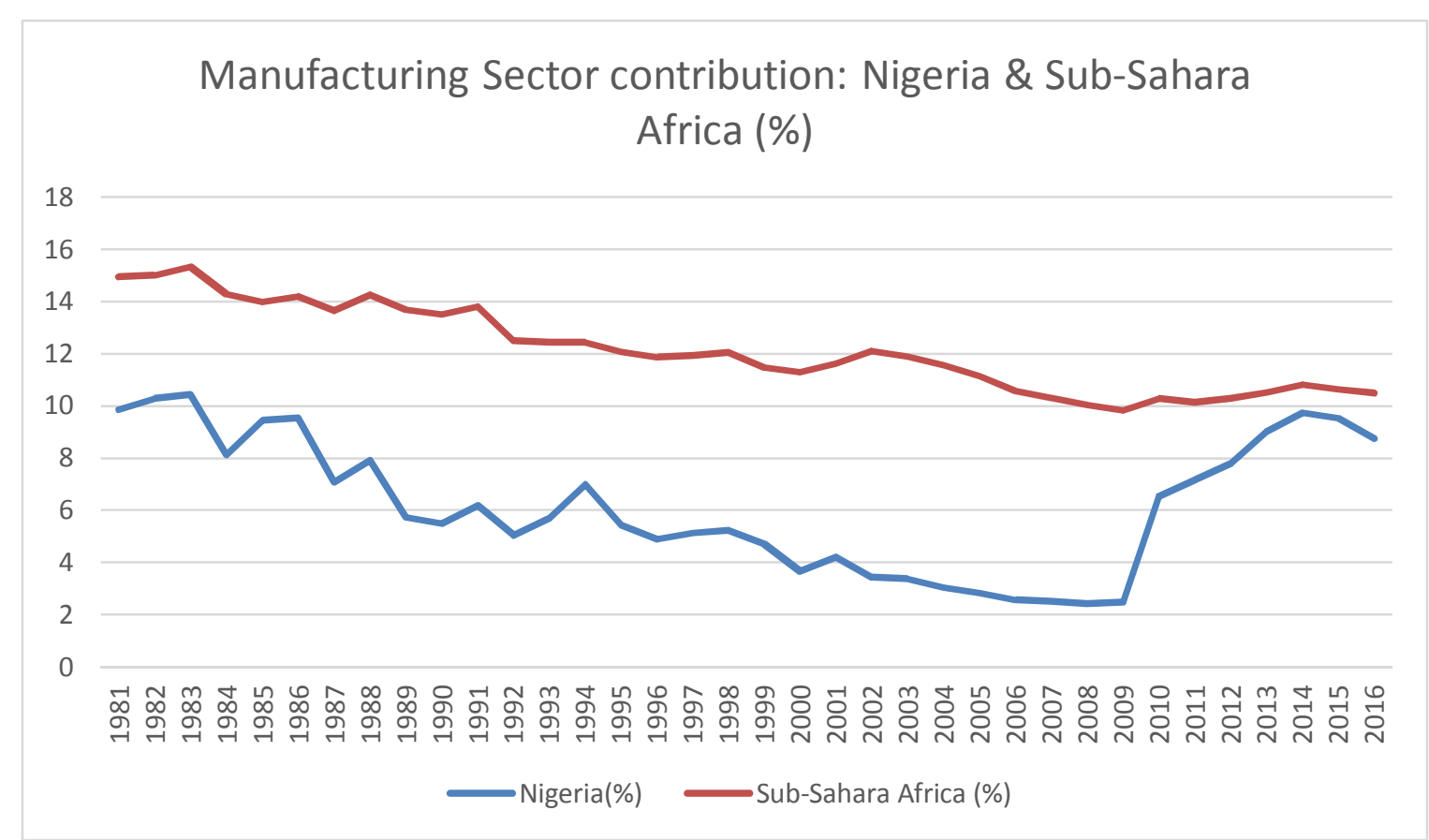

Figure 3.3: Manufacturing Sector GDP Contributions

Source: Author's computation with data from World Bank National Accounts

From table 3.4 above, Nigeria's manufacturing sector contribution to GDP is well below the average of the SubSahara Africa countries. Between 1981 and 2016, the highest contribution was in 1983 with a percentage contribution of 10.4 for Nigeria against 15.3 percent recorded by sub-Saharan African countries. A 2.4 percent contribution in 2009 was Nigeria's lowest contribution, while Sub-Saharan African countries recorded an average of 9.8 percent in the same year.

\subsubsection{Social Deformity}

\subsubsection{Weak Institutions and Systemic Corruption}

By institution, the institutionalists mean customs, social values, social habits, laws, and way of living as well as mode of thinking. The role of institutions in economic life is, therefore, imperative and emphasized in any developmental process. In institutionalism, therefore, the economic life of every economy is regulated by economic institutions and not economic laws (Jhingan et al, 2012). One major impediment to national development of Nigeria is the erosion institutions. Nigeria's value system, culture, laws and mode of thinking have been damaged. Corruption, dishonesty, social injustice and lack of integrity have been institutionalized, accepted and accommodated as a norm in our society. As corroborated by Okowa (1994) "Nigerians are so dishonest, lazy and weak, we allowed dishonesty to grow deep that most people are not ready to work, everyone wants to get rich....systemic corruption defines a situation in which corruption has been institutionalized and raised to a level of structural parameter. It has become part of culture of society". The destructive nature of institutionalized corruption and dishonesty is evident across every breadth of Nigeria; be it in business activities, religion, politics, public and civil services, private sector engagements and even personal relationships. No one is to be trusted opportunities to serve have been reduced to an acceptable and accommodated opportunity to become super rich through selfish accumulation of wealth and brazen embezzlement and mistrust. There seem to be no sane one amongst us as the entire population no longer frowns at looters and dishonest people among us rather they are being celebrated to all the members of the society including the religious bodies.

Consequently, people have come to realize that hard work does not pay and that the easiest way to be wealthy is to be dishonest and to be 'connected' to those holding political powers who incidentally appropriate economic resources. Healthy competition and hard work which are drivers of growth and development are no longer prerequisites for success in our clime. For instance, one does not require any special effort or expertise to own an oil well in Nigeria; just knowing who allocates the economic resources is ticket to wealth and stupendous affluence. Same scenario apply to allocation of foreign exchange where allocations are given to the 'connected' ones who 
subsequently flood the forex parallel market with their 'free gifts' at a high premium to make unproductive super profits. These sharp practices are expressly sabotaging economic activities, growth and national development, as no meaningful progress can be made under such damaged value system and way of life.

The economic, social and developmental costs of corruption and dishonesty in Nigeria cannot be overemphasized. Some scholars like Okowa (1994) and Ndiyo (2008) believes that corruption is primarily to major obstacle to Nigeria's quest for development. It has deformed every aspect of our economic life and human existence, and the economic and social losses cannot be appropriately quantified. Their position is also corroborated by some statistical evidence. For instance, a recent survey conducted by the National Bureau of Statistics between June 2015 and May 2016, revealed that Nigerians paid about N400 billion or $\$ 4.6$ billion as bribes in 2016 to public officials. The objective of the survey was to evaluate the quality and integrity of public services in Nigeria. Quoting the report "Corruption is the bane of any progressive society. It stifles entrepreneurship, professionalism and erodes the value of hard work and honesty, and is one of the root causes of under-development in our society. Over the years, we have seen the effect of corruption manifesting across all sectors of society, with collusion across the public to private sectors to sports bodies and even civil society" (NBS, 2017). To put this report into proper perspective, the N400 billion paid by Nigerians as bribes to public officials represent 50 percent of the total internally generated revenue (IGR) of the 36 states of the federation in 2016. This is the enormity of financial and social damages inherent in corruption in Nigeria. It is, therefore, a major deformity which may have as well been inadvertently entrenched by Nigeria's distorted political economy.

\subsection{CONCLUSION AND POLICY RECOMMENDATIONS}

There is no gain stating the obvious that Nigeria is bedeviled with enormous economic and national developmental challenges. These challenges include but not limited to political instability, extreme poverty, high rate of unemployment, low and unstable economic growth, dearth of infrastructure and colossal depreciation of the Naira; others include militancy, regional agitations and/or resentment, insurgency, and corruption among others. This paper, therefore, is a theoretical attempt to adduce reasons why Nigeria has not made meaningful economic and national developmental progress in her chequerred history. The position of this paper, therefore, is that Nigeria's economic and national developmental challenges are attributable directly and indirectly to the country's political arrangement and distorted political history. The study believes that Nigeria as it is presently constituted is suffering from at least three major deformities; political, economic and social. Political deformity, however, is believed to have fuelled economic and social deformities in the country. 'True' Federalism is an arrangement between governments, a constitutional device whereby powers of government within the country are shared between a national country wide government and member of a region territorially localized government in such a way that each exist as a government separately and independently from the others operating directly and independently on persons and properties within its territorial area with a will of its own and its own apparatus for the conduct of an authority in some matters exclusive of all others. Its purpose is to enable each group free from interference or control by the others to govern itself in matters of local concern leaving matters of common interest to be managed centrally, and those which are of both local and national concern to be administered concurrently. Federal political orders are therefore, most desirable as interesting solutions to accommodate differences among populations divided by ethnic, economic or cultural cleavages yet seeking common, often democratic order.

This paper, therefore concludes that Nigeria's version of Federalism having been distorted, breeds instability, corruption, unproductive consumption and laziness in her political economy; as well as a sense of deprivation and inequality between the Federal Government and the 'Federating' States on one hand, and the different ethnic nationalities or regions that make up the Federal Republic of Nigeria. As a consequence, therefore, conventional or orthodox economic theories and policies may not be effective to remedy the enormity of her developmental challenges, without pulling down the entire architecture of her current political economy, given that it is structurally deformed and therefore, constitute impediments to development.

The paper recommends, therefore, holistic revolution of Nigeria's political economy with the following specifics; a new and true Federalist Constitution. A true Federalist Constitution that will guarantee state or zonal independence and autonomy in terms of government powers and economic resources is most desirable in Nigeria. The benefits that are derivable from such political arrangement are positively revolutionary for economic and national development. Firstly, making the centre (Federal Government) weaker in terms of power and economic resources, will to a greater extent guarantee federal stability. It will greatly reduce the heighted clamour and injurious politicking to seize power at the centre for the purpose of overseeing the allocation of economic resources among different ethnic nationalities in Nigeria. Thus, such arrangement would make the centre less attractive and supremely powerful. Also, given the diversities, ethnic differences and/or the heterogeneous configuration of Nigeria, most (if not all) of the ethnic based agitations that seem to destabilize the country presently would at best be domesticated if not 
totally eliminated. Secondly, the diversification of the Nigerian economy would be guaranteed under such equitable and competitive political order. One major attribute of a capitalist economy is competition among economic agents for ownership of economic resources. True federalist constitution that guarantees each federating unit or zone full control of resources found in the region to be used for its development while royalties are paid to the centre. This would engender healthy competition and rivalry between states or zones, thereby, eliminating the current unproductive consumptions and noncompetitive order inherent in Nigeria's political economy. Once the 'free' monthly oil largesse from Abuja is eliminated, each federating states or zones would be forced to look inwards to find and develop economic resources they have comparative advantage over others. The much clamoured economic and revenue diversification would easily be achieved by healthy competition. Thus, if federating autonomy or separateness of government power is enshrined, the federating states or zones would vigorously pursue and chart the course of its development according to its pace and resources available at its disposal without suffocating others or being suffocated by other constituent units. It is on record that Nigeria made significant and tremendous progress politically and economically in the late 1950s and early 1963s when the political economy was regionally organized which guaranteed economic and regional autonomy to the federating regions.

Finally, our damaged institutions: value system, norms, customs and way of thinking need to be repaired and made stronger. Systemic corruption is cancerous and requires coordinated and proactive approach to expunge. Emphasis, therefore, should be placed on prevention rather than the present reactive approach of 'fighting' corruption. One of such proactive approach to curb corruption and dishonesty is to put in place a social system which rewards hard work. Secondly, politics and public office positions should be made less attractive in monetary gains. The monetization of politics and elections in Nigeria should be vigorously de-emphasized. Social engineering must to be effected which would remind every Nigerian that a call to leadership is a call to service and not for selfaccumulation of wealth. If Nigeria can succeed in revolutionizing her structurally damaged political economy to entrench 'true' federalism, her underlying and enormous economic potentials shall no longer be emasculated. This is the only feasible route to Nigeria attaining economic and national development that has eluded her for decades.

\section{REFERENCES}

Adesina, D. (2017, January 9). Nigeria: A Case for True Federalism. Thisday Newspaper. Retrieved from http://www.thisdaylive.com/index.php/2017/01/09/nigeria-a-case-for-true-federalism/.

Akande, B. (2017a, July 25). Replace 1999 Constitution with 1963 Republican Constitution. The Punch Newspapers. Retrieved from http://punchng.com/replace-1999-constitution-with-1963-republican-constitution.

Akande, B. (2017b, July 01). Monetization of Politics is Eroding our Political System. The Punch Newspapers. Retrieved from http://punchng.com/monetization-of-politics-is-eroding-our-political-system.

Amasike, U. (2017, July 17). Non-oil Export and Federalism. The Nation, p.18.

Babalola, A. (2017, July 2). FG Should Restructure Nigeria before next Election. The Punch Newspaper. Retrieved from http://punchng.com/fg-should-restructure-nigeria-before-the-next-election.

Central Bank of Nigeria. (2015). Statistical Bulletin. CBN, Abuja.

Debt Management Office. (Various). Public Debt Outstanding. Retrieved from https://www.dmo.gov.ng

Elazar, B. (1987). Exploring Federalism. Tuscaloosa: University of Alabama Press

Federal Republic of Nigeria (1999). Constitution.

Jhinghan, M.L., M. Girija and Sasikala, L. (2012). History of Economic Thought. Third edition. Vrinda Publications $(P)$, New Delhi, India.

Jhinghan, M.L. (2011). The Economics of Development and Planning. 40 ${ }^{\text {th }}$. Vrinda Publications (P), New Delhi, India.

Keynes, J. M. (1936). The General Theory of Employment, Interest Rate and Money: London: Macmillian.

Moodle (2014). Federalism. Retrieved from http://plato.stanford.edu/entries/federalism

National Bureau of Statistics (2017). National Corruption Survey. Retrieved from http://www.nigerianstat.gov.ng

Ndiyo, N.A. (2008). Poverty to Sustainable Development (A Community Based Approach). University of Calabar Printing Press, Calabar.

Nwabueze, B.O. (1983). Federalism in Nigeria under the Presidential Constitution. Sweet and Maxwell, London.

Okowa, W.J. (1996). How the Tropics Underdeveloped the Negros: A Questioning Theory of Development. Paragraphics, Port Harcourt.

Okowa, W.J. (1994). Oil, Systemic Corruption, Abdulistic Capitalism and Nigerian Development Policy: A Political Economy. Paragraphics, Port Harcourt.

Ohale, L and J.I Onyema (2001). Foundations of Macroeconomics. Springfield Publishers, Nigeria.

Oladesu, E. (2017, August 1). Ironsi: Genesis of Lopsided Federalism. The Nation, p.31

Ojo, G. (2017, July 18). Travails of Federalism. The Nation, p.20. 
Todaro, M. P. and Smith, S. C. (2011). Economic Development. 11 $1^{\text {th }}$ edition. Pearson Education Limited, Edinburgh Gale, England.

Watts, R.L. (1999). Federalism, Federal Political Systems, and Federations. Annual Review of Political Science; 1: 117-37.

Cite this Article: Nwaeze NC (2017). 'True' Federalism in a well-structured Nigeria: The Panacea to her Economic Development Challenges. Greener Journal of Economics and Accountancy, 6(2): 026-042, http://doi.org/10.15580/GJEA.2017.2.090417119 